\title{
Evaluation of Parameterization Schemes in the WRF Model for Estimation of Mixing Height
}

\author{
R. Shrivastava, ${ }^{1}$ S. K. Dash, ${ }^{2}$ R. B. Oza, ${ }^{1}$ and D. N. Sharma ${ }^{3}$ \\ ${ }^{1}$ Radiation Safety Systems Division, Bhabha Atomic Research Centre, Mumbai 400 085, India \\ ${ }^{2}$ Centre for Atmospheric Sciences, Indian Institute of Technology Delhi, New Delhi 110 016, India \\ ${ }^{3}$ Health Safety and Environment Group, Bhabha Atomic Research Centre, Mumbai 400 085, India \\ Correspondence should be addressed to R. Shrivastava; roopa@barc.gov.in
}

Received 22 October 2013; Revised 14 January 2014; Accepted 14 January 2014; Published 26 February 2014

Academic Editor: Daiwen Kang

Copyright (C) 2014 R. Shrivastava et al. This is an open access article distributed under the Creative Commons Attribution License, which permits unrestricted use, distribution, and reproduction in any medium, provided the original work is properly cited.

\begin{abstract}
This paper deals with the evaluation of parameterization schemes in the WRF model for estimation of mixing height. Numerical experiments were performed using various combinations of parameterization schemes and the results were compared with the mixing height estimated using the radiosonde observations taken by the India Meteorological Department (IMD) at Mangalore site for selected days of the warm and cold season in the years 2004-2007. The results indicate that there is a large variation in the mixing heights estimated by the model using various combinations of parameterization schemes. It was seen that the physics option consisting of Mellor Yamada Janjic (Eta) as the PBL scheme, Monin Obukhov Janjic (Eta) as the surface layer scheme, and Noah land surface model performs reasonably well in reproducing the observed mixing height at this site for both the seasons as compared to the other combinations tested. This study also showed that the choice of the land surface model can have a significant impact on the simulation of mixing height by a prognostic model.
\end{abstract}

\section{Introduction}

Prognostic atmospheric models are used as meteorological drivers to air pollution models in the absence of representative measured meteorological data for a site. These models generally provide wind speed, wind direction, temperature, humidity, rainfall, and mixing height values to the air pollution models. Many times, the resolution at which these models are integrated is too coarse to resolve the exchanges of heat, momentum, and moisture taking place at the air soil interface and hence these exchanges have to be parameterized in atmospheric models. Parameterization schemes may also be included in an atmospheric model for the representation of atmospheric phenomena whose explicit treatment may become too prohibitive due to cost and computer limitations. A weather model includes parameterizations for radiation, surface layer fluxes, turbulence, cumulus convection, and clouds. Generally there are six to seven schemes available for representation of each of these processes with its own merits and demerits depending upon the terrain, geography, and climate of the area under consideration. Mixing height is an important input to air pollution models since the transport and extent of mixing of pollutants depend on it. The mixing in the atmosphere primarily takes place through convective and mechanical processes. During the daytime, differential heating due to solar radiation sets up strong thermals in the atmosphere and the convective processes dominate whereas, during the nighttime, mechanical processes are responsible for the turbulent mixing. The variation of mixing height with varying parameterization schemes was studied by other investigators also. For example, Shin and Hong [1] intercompared five Planetary Boundary Layer (PBL) schemes in the WRF model for a single day from the Cooperative Atmosphere Surface Exchange Study (CASES-99) field program. They reported a large variation in the mixing height values computed by the five schemes in the daytime and nighttime. Similarly Han et al. [2] had also evaluated five PBL schemes in the MM5 model for the East Asian domain for March 2001 and reported a large difference in the mixing heights predicted by the various combinations of parameterization schemes. 


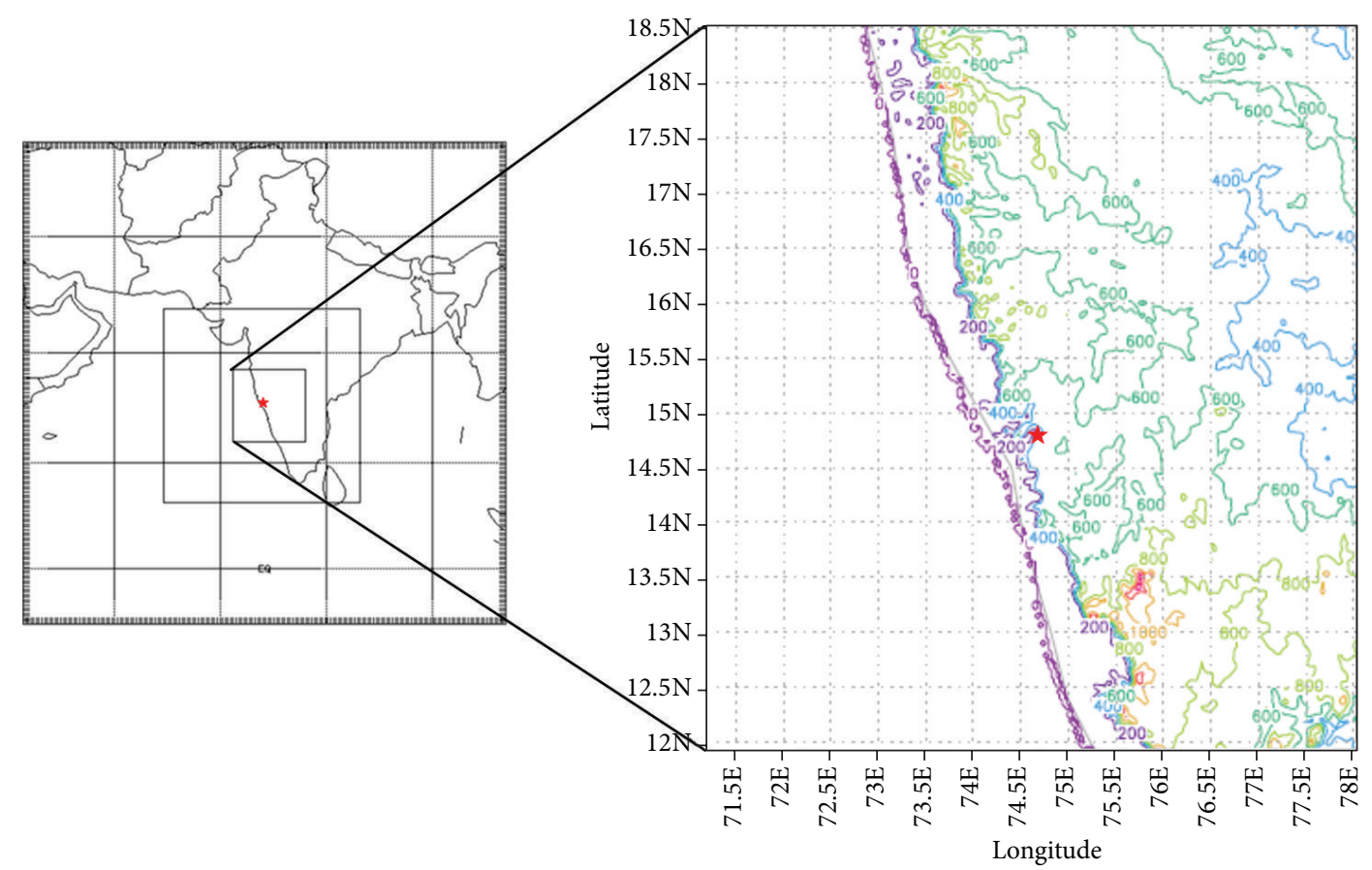

FIgURE 1: Model domains and the topography of the inner domain (red star denotes the plant site).

TABLE 1: Description of parameterization schemes.

\begin{tabular}{lccc}
\hline Land surface & Surface layer & Planetary boundary layer & Combination \\
\hline & Monin Obukhov & YSU & A \\
Thermal diffusion & Monin Obukhov & ACM2 (Pleim) & B \\
& Monin Obukhov (Janjic Eta) & Mellor Yamada Janjic (Eta) & D \\
& QNSE & QNSE & F \\
Noah land surface model & Monin Obukhov & YSU & E \\
\hline
\end{tabular}

YSU: Yonsei University; ACM2: Asymmetric Convective Model version 2; QNSE: Quasi-Normal Scale Elimination.

Hu et al. [3] compared the 3-month mean diurnal variations of the simulated mixing heights using different combination of parameterization schemes in the WRF model with the observed values for South East Texas.

The present study focuses on the evaluation of parameterization schemes in the WRF model for estimation of mixing height for Kaiga site. Kaiga is one of the sites where nuclear power plants are operated for generation of electricity by Nuclear Power Corporation of India Ltd (NPCIL). It is a complex site with tall hills, evergreen forests, a reservoir, and so forth. Weather forecasting is important in the nuclear industry because of the aid it can provide in handling an emergency situation. However the weather forecast model needs to be validated/tuned with proper selection of parameterization schemes for it to be used in case of an emergency situation. Also many times a weather model is coupled with an offline atmospheric dispersion model for prediction of concentration. In order to validate the mixing height estimated by the WRF model, the radiosonde observations taken by the India Meteorological Department (IMD) are utilized. Since radiosonde data for Kaiga site are not available, the radiosonde data from the nearby radiosonde observation station, Mangalore, are utilized for this purpose. The Mangalore station is at a distance of $\sim 300 \mathrm{~km}$ from Kaiga site. It should be noted that the model values were also extracted at this location for comparison with observed values. The cases selected for simulation correspond to selected days in the warm and cool season. Description of the model domain, numerical experiments, WRF model set-up, and physics parameterizations used is given in Section 2 and the results are presented in Section 3.

\section{Model and Methodology}

The study domain covers south west India centered at the Kaiga Generating Station (KGS) $\left(14^{\circ} 51^{\prime} 48^{\prime \prime} \mathrm{N}, 74^{\circ} 26^{\prime} 31^{\prime \prime} \mathrm{E}\right)$ as shown in Figure 1. The WRF model version 3.1.1 (Skamarock et al. [4]; Wei et al. [5]) is integrated using three nested domains with grid spacing varying from $27 \mathrm{~km}, 9 \mathrm{~km}$, and 
TABLE 2: Description of experiments.

\begin{tabular}{|c|c|c|}
\hline Simulation period & Case & Experiment \\
\hline 600Z 26 December 2004-00Z 29 December 2004 & \multirow{4}{*}{ Minimum temperature } & TMN1 \\
\hline 00Z 17 January 2005-00Z 20 January 2005 & & TMN2 \\
\hline 00Z 26 January 2006-00Z 29 January 06 & & TMN3 \\
\hline 00Z 14 November 2007-00Z 17 November 07 & & TMN4 \\
\hline 00Z 13 March 2004 -00Z 16 March 2004 & \multirow{4}{*}{ Maximum temperature } & TMX1 \\
\hline 00Z 04 April 2005-00Z 07 April 2005 & & TMX2 \\
\hline 00Z 23 February 2006-00Z 26 February 2006 & & TMX3 \\
\hline 00Z 24 April 2007-00Z 27 April 2007 & & TMX4 \\
\hline
\end{tabular}

TABLE 3: Comparison of model generated mixing height with the observed values for cases TMN1-TMN4.

\begin{tabular}{|c|c|c|c|c|c|c|c|c|}
\hline & $\mathrm{A}(\mathrm{m})$ & $\mathrm{B}(\mathrm{m})$ & $\mathrm{C}(\mathrm{m})$ & $\mathrm{D}(\mathrm{m})$ & $\mathrm{E}(\mathrm{m})$ & $\mathrm{F}(\mathrm{m})$ & $\mathrm{O}(\mathrm{m})$ & Case study \\
\hline 12Z 26 December 2004 & 77 & 136 & 112 & 145 & 146 & 800 & 300 & \multirow{6}{*}{ TMN1 } \\
\hline 00Z 27 December 2004 & 248 & 77 & 339 & 391 & 392 & 565 & 150 & \\
\hline 12Z 27 December 2004 & 227 & 169 & 107 & 145 & 398 & 1069 & 300 & \\
\hline 00Z 28 December 2004 & 405 & 159 & 546 & 395 & 393 & 2577 & 150 & \\
\hline 12Z 28 December 2004 & 34 & 164 & 118 & 146 & 399 & 400 & 400 & \\
\hline 00Z 29 December 2004 & 305 & 103 & 375 & 144 & 396 & 1064 & 100 & \\
\hline 12Z 17 January 2005 & 256 & 293 & 493 & 401 & 808 & 580 & 900 & \multirow{6}{*}{ TMN2 } \\
\hline 00Z 18 January 2005 & 29 & 33 & 30 & 145 & 145 & 144 & 350 & \\
\hline 12Z 18 January 2005 & 112 & 189 & 297 & 1568 & 580 & 2073 & 600 & \\
\hline 00Z 19 January 2005 & 30 & 38 & 32 & 145 & 144 & 144 & 200 & \\
\hline 12Z 19 January 2005 & 215 & 213 & 360 & 400 & 806 & 807 & 700 & \\
\hline 00Z 20 January 2005 & 159 & 50 & 30 & 144 & 145 & 144 & 100 & \\
\hline 12Z 26 January 2006 & 350 & 258 & 417 & 146 & 575 & 575 & 550 & \multirow{5}{*}{ TMN3 } \\
\hline 00Z 27 January 2006 & 133 & 53 & 115 & 142 & 142 & 253 & 100 & \\
\hline 12Z 27 January 2006 & 237 & 192 & 236 & 146 & 399 & 258 & 650 & \\
\hline 00Z 28 January 2006 & 121 & 39 & 234 & 394 & 143 & 1540 & 100 & \\
\hline 00Z 29 January 2006 & 232 & 84 & 269 & 142 & 252 & 2041 & 200 & \\
\hline 00Z 14 November 2007 & 309 & 203 & 347 & 145 & 398 & 397 & 200 & \multirow{6}{*}{ TMN4 } \\
\hline 12Z 14 November 2007 & 137 & 54 & 171 & 142 & 143 & 253 & 100 & \\
\hline 00Z 15 November 2007 & 133 & 206 & 105 & 146 & 146 & 258 & 100 & \\
\hline 12Z 15 November 2007 & 101 & 57 & 29 & 142 & 143 & 565 & 480 & \\
\hline 00Z 16 November 2007 & 35 & 231 & 202 & 145 & 145 & 395 & 100 & \\
\hline \multirow[t]{2}{*}{$12 Z 16$ November 2007} & 40 & 37 & 29 & 141 & 141 & 787 & 400 & \\
\hline & $3 / 23$ & $3 / 23$ & $1 / 23$ & $1 / 23$ & $13 / 23$ & $2 / 23$ & & \\
\hline
\end{tabular}

The bold values refer to the best match between model and observation.

$3 \mathrm{~km}$. The terrain and land use data for the innermost domain with $3 \mathrm{~km}$ grid resolution were taken from $30^{\prime}$ data, for domain with $9 \mathrm{~km}$ resolution from $5^{\prime}$ data and for the domain with $27 \mathrm{~km}$ resolution from $10^{\prime}$ data available from the United States Geological Survey (USGS). The parameterization schemes tested in this study are defined in Table 1. The PBL schemes tested are Yonsei University, (YSU, Hong et al. [6]), Mellor Yamada Janjic Eta (MYJ, Janjic [7, 8]), Asymmetric Convective Model, (ACM2, Pleim [9]), and Quasi Normal Scale Elimination (QNSE, Sukoriansky et al. [10, 11]). The surface layer (SL) schemes used are Monin Obukhov (Monin and Obukhov [12]), Monin Obukhov Janjic Eta (MYJ, Monin and Obukhov [12], Janjic [13]), and Quasi-Normal Scale
Elimination (QNSE, Sukoriansky et al. $[10,11])$ and the land surface models (LSM) used are thermal diffusion (Dudhia [14]) and the Noah land surface model (Chen and Dudhia [15]). The other physical parameterizations are identical for all experiments which are Rapid radiation Transfer Model for long-wave radiation (RRTM, Mlawer et al. [16]), Dudhia (Dudhia [17]) for short-wave radiation, Kain Fritsch scheme for cumulus parameterization (Kain and Fritsch [18], J. S. Kain [19]) and Ferrier new Eta (Ferrier et al. [20]) scheme for representing microphysical processes in the clouds. A total of six combinations of parameterization schemes are considered which are defined in the Table 1. The National Centers for Environmental Prediction (NCEP) Final Analysis data 
TABLE 4: Comparison of model generated mixing height with the observed values for cases TMX1-TMX4.

\begin{tabular}{|c|c|c|c|c|c|c|c|c|}
\hline & $\mathrm{A}(\mathrm{m})$ & $\mathrm{B}(\mathrm{m})$ & $\mathrm{C}(\mathrm{m})$ & $\mathrm{D}(\mathrm{m})$ & $\mathrm{E}(\mathrm{m})$ & $\mathrm{F}(\mathrm{m})$ & $\mathrm{O}(\mathrm{m})$ & Case study \\
\hline 12Z March 2004 & 256 & 293 & 493 & 401 & 808 & 580 & 900 & \multirow{6}{*}{ TMX1 } \\
\hline 00Z 14 March 2004 & 29 & 33 & 30 & 145 & 145 & 144 & 350 & \\
\hline 12Z 14 March 2004 & 112 & 189 & 297 & 1568 & 580 & 2073 & 900 & \\
\hline 00Z 15 March 2004 & 30 & 38 & 32 & 145 & 144 & 144 & 200 & \\
\hline 12Z 15 March 2004 & 215 & 213 & 360 & 400 & 806 & 807 & 700 & \\
\hline 00Z 16 March 2004 & 159 & 50 & 30 & 144 & 145 & 144 & 100 & \\
\hline 12Z 04 April 2005 & 257 & 365 & 399 & 580 & 809 & 809 & 900 & \multirow{6}{*}{ TMX2 } \\
\hline 00Z 05 April 2005 & 30 & 39 & 30 & 145 & 146 & 145 & 150 & \\
\hline 12Z 05 April 2005 & 86 & 237 & 338 & 1575 & 581 & 2084 & 900 & \\
\hline 00Z 06 April 2005 & 30 & 59 & 30 & 145 & 146 & 145 & 350 & \\
\hline 12Z 06 April 2005 & 117 & 272 & 226 & 147 & 403 & 587 & 800 & \\
\hline 00Z 07 April 2005 & 30 & 39 & 30 & 146 & 147 & 259 & 300 & \\
\hline 12Z 23 February 2006 & 117 & 153 & 276 & 146 & 577 & 580 & 600 & \multirow{6}{*}{ TMX3 } \\
\hline 00Z 24 February 2006 & 89 & 35 & 42 & 144 & 143 & 1062 & 100 & \\
\hline 12Z 24 February 2006 & 84 & 1017 & 206 & 146 & 576 & 2058 & 400 & \\
\hline 00Z 25 February 2006 & 134 & 86 & 29 & 143 & 571 & 254 & 100 & \\
\hline 12Z 25 February 2006 & 331 & 223 & 355 & 398 & 575 & 398 & 900 & \\
\hline 00Z 26 February 2006 & 198 & 52 & 29 & 395 & 144 & 2049 & 100 & \\
\hline 12Z 24 April 2007 & 429 & 409 & 533 & 811 & 809 & 1083 & 800 & \multirow{6}{*}{ TMX4 } \\
\hline 00Z 25 April 2007 & 30 & 53 & 41 & 145 & 579 & 258 & 150 & \\
\hline 12Z 25 April 2007 & 214 & 263 & 350 & 588 & 584 & 819 & 700 & \\
\hline 00Z 26 April 2007 & 58 & 54 & 30 & 147 & 146 & 261 & 50 & \\
\hline 12Z 26 April 2007 & 422 & 436 & 443 & 585 & 585 & 1088 & 900 & \\
\hline 00Z 27 April 2007 & 30 & 57 & 30 & 146 & 146 & 260 & 100 & \\
\hline No. of successes & - & $2 / 24$ & - & $1 / 24$ & $18 / 24$ & $3 / 24$ & & \\
\hline
\end{tabular}

The bold values refer to the best match between model and observation.

available at 6 hourly interval on a $1^{\circ} \times 1^{\circ}$ resolution are used to supply initial and boundary conditions. The model uses two-way nested boundary conditions and they are updated every 6 hours. A total of eight simulation cases are considered in the present study which are based on either maxima or minima in temperature and these are described in Table 2. This study focuses on the comparison of mixing height estimated by the model in the various combinations of parameterization schemes with the observed values. Each simulation is for a three-day period one on the day of occurrence, one day prior, and one day later to it. The mixing height computation by the model differs according to the PBL scheme used. The schemes YSU and ACM2 estimate mixing height based on the Richardson number whereas the remaining two PBL schemes namely MYJ and QNSE diagnose the mixing height on the basis of the turbulent kinetic energy (TKE). While both the approaches may be theoretically correct, the one which produces values of mixing height which compare well with the observation can be considered to be the better approach. In addition to the model's own diagnosis of mixing height, the temperature profile given by the model was also used to estimate the mixing height based on the Holtzworth [21] method. In this case, the variation between different combinations of schemes due to varying methodologies is eliminated and the differences observed are only due to those in the temperature profile of the model. Both the methods of estimating mixing height are in turn compared with the observation.

\section{Results and Discussion}

The mixing heights obtained in all combinations of parameterization schemes tested are shown in Tables 3 and 4 for the experiments TMN1-TMN4 and TMX1-TMX4, respectively, with the best performing combinations presented in bold font. The observed mixing heights are calculated from the radiosonde temperature profile following the method of Holtzworth [21]. For a three-day simulation, six radiosonde profiles are available for comparison (one each at $00 \mathrm{Z}$ and 12Z). However, sometimes, a particular sounding may not be available and hence that time is not considered in the analysis for example, $12 Z$ on January 28, 2006. In order to remove the dependence of mixing height on parameterization schemes, the mixing height values are also generated by using Holtzworth method on the model derived temperature profiles and the results are presented in Table 5 for experiments TMN1-TMN4 and in Table 6 for experiments TMX1-TMX4. 
TABLE 5: Comparison of model generated mixing height (using Holtzworth's method) with the observed values for experiments TMN1TMN4

\begin{tabular}{|c|c|c|c|c|c|c|c|c|}
\hline & $\mathrm{A}(\mathrm{m})$ & $\mathrm{B}(\mathrm{m})$ & $\mathrm{C}(\mathrm{m})$ & $\mathrm{D}(\mathrm{m})$ & $\mathrm{E}(\mathrm{m})$ & $\mathrm{F}(\mathrm{m})$ & $\mathrm{O}(\mathrm{m})$ & Case study \\
\hline 12Z 26 December 2004 & 1300 & 1400 & 550 & 1200 & 450 & 1250 & 300 & \multirow{6}{*}{ TMN1 } \\
\hline 00Z 27 December 2004 & 100 & 100 & - & 150 & 50 & 200 & 150 & \\
\hline 12Z 27 December 2004 & 1350 & 1300 & 650 & 1300 & 400 & 1450 & 300 & \\
\hline 00Z 28 December 2004 & - & 80 & - & 50 & 80 & - & 150 & \\
\hline 12Z 28 December 2004 & 1100 & 800 & 500 & 1200 & 500 & 1300 & 400 & \\
\hline 00Z 29 December 2004 & - & 80 & - & 70 & 80 & 50 & 100 & \\
\hline 12Z 17 January 2005 & 600 & 600 & 600 & 580 & 550 & 625 & 900 & \multirow{6}{*}{ TMN2 } \\
\hline 00Z 18 January 2005 & 200 & 180 & 200 & 150 & 100 & 150 & 350 & \\
\hline $12 Z 18$ January 2005 & 1300 & 1200 & 1000 & 1400 & 950 & 1350 & 600 & \\
\hline 00Z 19 January 2005 & 250 & 300 & 150 & 200 & 100 & 250 & 200 & \\
\hline 12Z 19 January 2005 & 1100 & 1050 & 900 & 1150 & 850 & 1150 & 700 & \\
\hline 00Z 20 January 2005 & 200 & 200 & 80 & 150 & 80 & 200 & 100 & \\
\hline 12Z 26 January 2006 & 1400 & 1800 & 1050 & 2000 & 900 & 2000 & 550 & \multirow{5}{*}{ TMN3 } \\
\hline 00Z 27 January 2006 & 50 & 200 & 50 & 200 & 100 & 200 & 100 & \\
\hline 12Z 27 January 2006 & 1450 & 950 & 750 & 1400 & 700 & 1400 & 650 & \\
\hline 00Z 28 January 2006 & 50 & 50 & - & 50 & 100 & 100 & 100 & \\
\hline 00Z 29 January 2006 & 100 & 80 & - & 100 & 80 & 120 & 200 & \\
\hline 00Z 14 November 2007 & 150 & - & - & - & - & - & 200 & \multirow{6}{*}{ TMN4 } \\
\hline 12Z 14 November 2007 & 550 & 650 & 750 & 1250 & 600 & 1300 & 100 & \\
\hline 00Z 15 November 2007 & 50 & 120 & - & 120 & 100 & 180 & 100 & \\
\hline 12Z 15 November 2007 & 500 & 490 & 400 & 900 & 700 & 950 & 480 & \\
\hline 00Z 16 November 2007 & 110 & 120 & 50 & 150 & 100 & 200 & 100 & \\
\hline 12Z 16 November 2007 & 1250 & 1100 & 1000 & 1200 & 900 & 1200 & 400 & \\
\hline No. of successes & $2 / 23$ & $1 / 23$ & $1 / 23$ & $2 / 23$ & $16 / 23$ & $1 / 23$ & & \\
\hline
\end{tabular}

The bold values refer to the best match between model and observation.

Here also, the best performing combinations are presented in bold font. The Holtzworth method works on the basis of intersection of the temperature profile with the dry adiabatic line drawn from the surface with the maximum temperature of the day for the $12 \mathrm{Z}$ mixing height and with the minimum temperature $+5^{\circ} \mathrm{C}$ for the $00 \mathrm{Z}$ mixing height. In cases where the two curves do not intersect, the mixing height cannot be determined. These are represented by a "- " in Tables 5 and 6. The model derived mixing heights are shown in columns $\mathrm{A}-\mathrm{F}$ and the observed mixing height is presented in column O. From Tables 3 and 4, one can estimate the magnitude of variation among the different parameterization schemes for estimation of mixing height at a given time making a parametric study so very essential. The differences in the model estimates of mixing height arise because of the various methods of calculation used in the schemes. For example at $12 \mathrm{Z}$ 26th December 2004, the observed mixing height from the radiosonde data was $300 \mathrm{~m}$. The model generated values range from $77 \mathrm{~m}$ to $800 \mathrm{~m}$ indicating a large variation as compared to the observation. Similar variation is noted at other times also. It is also important to note the role of the land surface model in estimation of mixing height. In an atmospheric model, the land surface model is used to calculate the exchange coefficients of heat, momentum, and moisture at the air soil interface which is used in the estimation of heat, momentum, and moisture fluxes. These fluxes provide the lower boundary condition for vertical transport in the PBL. The five-layer thermal diffusion model is a simple soil temperature model. The layers are $1 \mathrm{~cm}, 2 \mathrm{~cm}$, $4 \mathrm{~cm}, 8 \mathrm{~cm}$, and $16 \mathrm{~cm}$ thick. Below this the temperature is fixed at a deep layer average value. The soil moisture values are season dependent constant values based on land use categorization without considering the effects of vegetation. The Noah land surface model on the other hand predicts soil temperature and moisture in 4 layers extending $10 \mathrm{~cm}, 30 \mathrm{~cm}$, $60 \mathrm{~cm}$, and $100 \mathrm{~cm}$ from the surface and summing up to $2 \mathrm{~m}$ below the surface. It includes land use, monthly vegetation fraction, and evapotranspiration in the estimation of sensible and latent heat fluxes. In general, it is seen that the values of mixing height obtained using the Noah land surface model are better than those obtained with the thermal diffusion model for identical combinations of PBL/SL schemes (i.e., $\mathrm{E}$ is better than $\mathrm{D}$ and $\mathrm{C}$ is better than $\mathrm{A}$ ) due to better representation of physical processes leading to transfer of heat, momentum, and moisture at the air soil interface. In fact Stensrud [22] says that "if variations in surface conditions occur over small scales, then the resulting rapid horizontal changes in the values of surface fluxes can lead to the development of non-classical mesoscale circulations, such as vegetation or inland sea breezes." The model's representation of such processes are important for weather prediction for a complex terrain sites. For a given land surface model, 
TABLE 6: Comparison of model generated mixing height (using Holtzworth method) with the observed values for experiments TMX1-TMX4.

\begin{tabular}{|c|c|c|c|c|c|c|c|c|}
\hline & $\mathrm{A}(\mathrm{m})$ & $\mathrm{B}(\mathrm{m})$ & $\mathrm{C}(\mathrm{m})$ & $\mathrm{D}(\mathrm{m})$ & $\mathrm{E}(\mathrm{m})$ & $\mathrm{F}(\mathrm{m})$ & $\mathrm{O}(\mathrm{m})$ & Case study \\
\hline 12Z 13 March 2004 & 1200 & 950 & 950 & 1200 & 920 & 1450 & 900 & \multirow{6}{*}{ TMX1 } \\
\hline 00Z 14 March 2004 & 220 & 150 & 250 & 250 & 200 & 200 & 350 & \\
\hline 12Z 14 March 2004 & 350 & 300 & 500 & 900 & 500 & 950 & 900 & \\
\hline 00Z 15 March 2004 & 150 & 180 & 180 & 200 & 200 & 250 & 200 & \\
\hline 12Z 15 March 2004 & 1150 & 950 & 800 & 1450 & 750 & 1400 & 700 & \\
\hline 00Z 16 March 2004 & 300 & 200 & 100 & 300 & 100 & 400 & 100 & \\
\hline 12Z 04 April 2005 & 950 & 950 & 950 & 1300 & 900 & 1300 & 900 & \multirow{6}{*}{ TMX2 } \\
\hline 00Z 05 April 2005 & 100 & 200 & 350 & 250 & 300 & 250 & 150 & \\
\hline 12Z 05 April 2005 & 100 & - & 500 & 700 & 550 & 800 & 900 & \\
\hline 00Z 06 April 2005 & 250 & 180 & 100 & 200 & 180 & 200 & 350 & \\
\hline 12Z 06 April 2005 & 300 & 400 & 200 & 250 & 300 & 250 & 800 & \\
\hline 00Z 07 April 2005 & 200 & 300 & 200 & 200 & 150 & 200 & 300 & \\
\hline 12Z 23 February 2006 & 1050 & 1150 & 750 & 1600 & 700 & 1600 & 600 & \multirow{6}{*}{ TMX3 } \\
\hline 00Z 24 February 2006 & - & 100 & 80 & 80 & - & 100 & 100 & \\
\hline 12Z 24 February 2006 & 1400 & 1300 & 700 & 1500 & 600 & 1500 & 400 & \\
\hline 00Z 25 February 2006 & 80 & 150 & 50 & 80 & 80 & 150 & 100 & \\
\hline 12Z 25 February 2006 & 1300 & 1350 & 950 & 1450 & 850 & 1450 & 900 & \\
\hline 00Z 26 February 2006 & - & 50 & 50 & 80 & 50 & 150 & 100 & \\
\hline 12Z 24 April 2007 & 700 & 700 & 750 & 700 & 750 & 700 & 800 & \multirow{6}{*}{ TMX4 } \\
\hline 00Z 25 April 2007 & 100 & 120 & 200 & 150 & 150 & 200 & 150 & \\
\hline 12Z 25 April 2007 & 400 & 350 & 450 & 400 & 450 & 500 & 700 & \\
\hline 00Z 26 April 2007 & 50 & 100 & 80 & 80 & 50 & 150 & 50 & \\
\hline 12Z 26 April 2007 & 800 & 700 & 700 & 1050 & 700 & 1100 & 900 & \\
\hline 00Z 27 April 2007 & 120 & 100 & 120 & 100 & 120 & 180 & 100 & \\
\hline No. of successes & $2 / 24$ & $3 / 24$ & - & $2 / 24$ & $15 / 24$ & $2 / 24$ & - & \\
\hline
\end{tabular}

The bold values refer to the best match between model and observation.

TABLE 7: Statistical analysis.

\begin{tabular}{lcccc}
\hline Statistic & TMN_E & TMN_HE & TMX_E & TMX_HE \\
\hline AVG_WRF $(\mathrm{m})$ & 318 & 385 & 423 & 498 \\
AVG_O (m) & 320 & 320 & 179 & 493 \\
MAE (m) & 123 & 159 & 0.84 & 125 \\
IOA & 0.86 & 0.83 & 0.75 & 0.91 \\
CORR & 0.74 & 0.76 & 229 & 0.86 \\
RMSE (m) & 160 & 222 & 186 \\
\hline
\end{tabular}

AVG_WRF: average of model, AVG_O: average of observation, MAE: mean absolute error, IOA: index of agreement, CORR: correlation coefficient, RMSE: root mean square error, TMN_E: experiments TMN1-TMN4, TMN_HE: experiments TMN1-TMN4 but using Holtzworth method, and TMX_E, TMX_HE: same as TMN_E, TMN_HE for the case studies TMX1-TMX4.

say the Noah LSM, the results with the Monin Obukhov (Janjic Eta) PBL scheme and the Mellor Yamada Janjic (Eta) surface layer scheme are better than those with the YSU PBL and Monin Obukhov surface layer scheme (i.e., E is better than C). Hence it is seen that it is a combined effect of all parameterization schemes which translates into a good simulation of mixing height by an atmospheric model. As already mentioned, the Holtzworth method was also used to estimate the mixing height based on the model derived temperature profile under various combinations of parameterization schemes. For a comparison of the two methods, the scatter plots of the model generated mixing heights with the observations are shown in Figures 2 and 3 for the case studies TMN1-TMN4 and TMX1-TMX4, respectively. Also, many statistical parameters like average of model, average of observation, mean absolute error, index of agreement, and root mean square error were computed and are presented in Table 7. From Figure 2, it is seen that the model's own diagnosis of mixing height is underpredicted whereas the same obtained using Holtzworth method on the model generated temperature profile is overpredicted. However the Holtzworth method used on the model derived temperature profile has a smaller intercept as compared to that of the model's own diagnosis of mixing height. The correlation coefficient and index of agreement obtained in both the cases are comparable. From Table 7, referring to the errors, namely, 


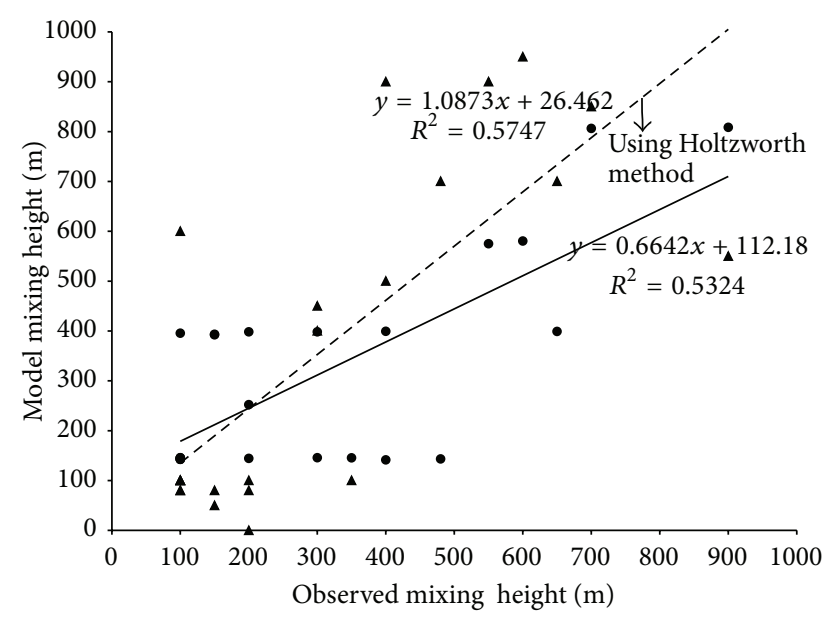

- Model mixing height in combination E

- Model mixing height using Holtzworth method in combination $\mathrm{E}$

FIGURE 2: Comparison of model generated (in combination E) mixing height with the observed values for experiments TMN1TMN4.

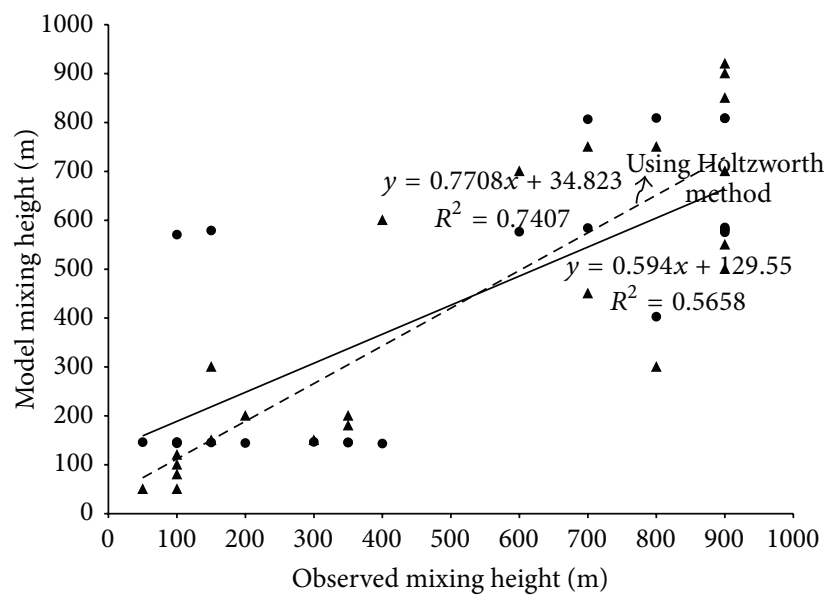

- Model mixing height in combination E

$\triangle$ Model mixing height using Holtzworth method in combination $\mathrm{E}$

FIgURE 3: Comparison of model generated (in combination E) mixing height with the observed values for experiments TMX1TMX4.

mean absolute and root mean square error, it is seen that the model's own estimation of mixing height is better than that obtained using the Holtzworth method on the model generated temperature profile on the basis of lower values of errors. The difference in the mean absolute error between the two methods is $\sim 12 \%$ in an average mixing height of $320 \mathrm{~m}$. Hence making a definite statement about any of the two methods being superior is not possible for the case studies TMN1-TMN4 based on the current simulations carried out. Similar analysis was done for the case studies TMX1-TMX4 also, with the scatter plot being shown in Figure 3. From the plot and the statistical analysis in Table 7, it can be concluded that for these cases, the mixing height computed using the Holtzworth method on the model generated temperature profile is better than the model's own estimation of mixing height based on the turbulent kinetic energy. All the statistical parameters computed for the case TMX_HE (referring to Holtzworth method on the model derived temperature profile for experiments TMX1-TMX4) are superior to the case TMX_E (referring to experiments TMX1-TXM4). From Table 4 , it is seen that on many occasions the mixing height at $12 \mathrm{Z}$ is underestimated by the model. Even if the land surface model chosen accounts for the physical processes occurring in the atmosphere, the coefficients/constants being used in the respective algorithms may require further refinement. When the Holtzworth method is applied on the model derived temperature profile in combination $\mathrm{E}$, this underestimation is eliminated. Hence for the experiments TMX1TXM4 corresponding to selected days in the warm season, the mixing height estimated using the Holtzworth method on the model derived temperature profile is better than the model's own estimation of mixing height. It is also to be noted that the application of the Holtzworth method on other combinations of parameterization schemes A, B, D, and $\mathrm{F}$ in this study leads to deterioration of model results and should be avoided. Finally to summarize, this study has shown that the set of parameterizations schemes defined by the combination $\mathrm{E}$ gives reasonable results for 13 out of 23 case studies for the cool season and 18 out of 24 case studies for the warm season mainly due to the Noah land surface model used. Nevertheless, this mixing height should still be verified by using the Holtzworth method on the model derived temperature profile obtained using the same combination of parameterization schemes for those locations where radiosonde data are available. This study also shows that the state-of-the-art parameterizations schemes in the WRF model still have scope for improvement.

Index of agreement

$$
\mathrm{IOA}=1-\frac{\sum_{i=1}^{N}\left(P_{i}-O_{i}\right)^{2}}{\sum_{i=1}^{N}\left(\left|P_{i}-O_{\text {mean }}\right|+\left|O_{i}-O_{\text {mean }}\right|\right)^{2}} .
$$

Pearson correlation coefficient

$$
\begin{aligned}
\operatorname{CORR}=\left(N\left(\sum_{i=1}^{N} O_{i} P_{i}\right)-\left(\sum_{i=1}^{N} O_{i}\right)\left(\sum_{i=1}^{N} P_{i}\right)\right) \\
\times\left(\left[N\left(\sum_{i=1}^{N} O_{i}^{2}\right)-\left(\sum_{i=1}^{N} O_{i}\right)^{2}\right]\right. \\
\left.\times\left[N\left(\sum_{i=1}^{N} P_{i}^{2}\right)-\left(\sum_{i=1}^{N} P_{i}\right)^{2}\right]\right)^{-1 / 2} .
\end{aligned}
$$

Mean absolute error

$$
\mathrm{MAE}=\frac{1}{N} \sum_{i=1}^{N}\left|P_{i}-O_{i}\right| .
$$


Root mean square error

$$
\mathrm{RMSE}=\sqrt{\frac{1}{N} \sum_{i=1}^{N}\left(P_{i}-O_{i}\right)^{2}}
$$

\section{Conclusions}

The numerical experiments carried out for the selection of the optimum combination of parameterization schemes for estimation of mixing height have shown that the physics option consisting of Mellor Yamada Janjic (Eta) as the PBL scheme, Monin Obukhov Janjic (Eta) as the Surface Layer scheme, and Noah land surface model performs reasonably well in reproducing the observed mixing height for almost all the cases considered for simulation as compared to the other combinations tested. The role played by the land surface model for a good simulation of mixing height was also emphasized. The application of the Holtzworth method on the model derived temperature profile to estimate mixing height as opposed to the model diagnosed mixing height suggests that during the warm season, the model derived mixing height based on the Holtzworth method matches reasonably well with the observations as opposed to the model diagnosed mixing height. However, for the cold season no such conclusive statement can be made. Such studies on the proper choice of parameterization schemes at a power plant site are useful when a prognostic weather model like WRF is to be coupled with an air quality model for atmospheric dispersion studies.

\section{Conflict of Interests}

The authors declare that there is no conflict of interests regarding the publication of this paper.

\section{Acknowledgments}

The authors express their gratitude to Dr. K. S. Pradeepkumar, Head Radiation Safety Systems Division, BARC, and Dr. R. N. Nair, (former Head), Environmental Modeling Section, BARC, for constant encouragement and fruitful discussions during the period of study. The authors also wish to thank the anonymous reviewers for useful suggestions and comments which have improved the quality of the paper. The FNL data for this study are from the Research Data Archive (RDA) which is maintained by the Computational and Information Systems Laboratory (CISL) at the National Center for Atmospheric Research (NCAR). NCAR is sponsored by the National Science Foundation (NSF). The original data are available from the RDA (http://rda.ucar.edu/) in dataset no. ds083.2.

\section{References}

[1] H. H. Shin and S. Y. Hong, "Intercomparison of planetary boundary-layer parameterizations in the WRF model for a single day from CASES-99," Boundary-Layer Meteorology, vol. 139, no. 2, pp. 261-281, 2011.
[2] Z. Han, H. Ueda, and J. An, "Evaluation and intercomparison of meteorological predictions by five MM5-PBL parameterizations in combination with three land-surface models," Atmospheric Environment, vol. 42, no. 2, pp. 233-249, 2008.

[3] X. M. Hu, J. W. Nielsen-Gammon, and F. Zhang, "Evaluation of three planetary boundary layer schemes in the WRF model," Journal of Applied Meteorology and Climatology, vol. 49, no. 9, pp. 1831-1844, 2010.

[4] W. C. Skamarock, J. B. Klemp, J. Dudhia et al., "A description of the advanced research WRF version 3," NCAR Technical Note, NCAR, Boulder, Colo, USA, 2008.

[5] W. Wei, B. Cindy, D. Michael et al., ARW Version 3 Modeling System User's Guide, 2009.

[6] S. Y. Hong, Y. Noh, and J. Dudhia, "A new vertical diffusion package with an explicit treatment of entrainment processes," Monthly Weather Review, vol. 134, no. 9, pp. 2318-2341, 2006.

[7] Z. I. Janjic, “The step-mountain coordinate: physical package," Monthly Weather Review, vol. 118, no. 7, pp. 1429-1443, 1990.

[8] Z. I. Janjic, "Nonsingular implementation of the Mellor Yamada level 2.5 Scheme in the NCEP Meso model," NCEP Office Note 437, 2002.

[9] J. E. Pleim, "A combined local and non-local closure model for the atmospheric boundary layer. Part I: model description and testing," Journal of Applied Meteorology and Climatology, vol. 46, no. 9, pp. 1383-1395, 2007.

[10] S. Sukoriansky, B. Galperin, and V. Perov, "Application of a new spectral theory of stably stratified turbulence to the atmospheric boundary layer over sea ice," Boundary-Layer Meteorology, vol. 117, no. 2, pp. 231-257, 2005.

[11] S. Sukoriansky, B. Galperin, and V. Perov, "A quasi-normal scale elimination model of turbulence and its application to stably stratified flows," Nonlinear Processes in Geophysics, vol. 13, no. 1, pp. 9-22, 2006.

[12] A. S. Monin and A. M. Obukhov, "Basic laws of turbulent mixing in the surface layer of the atmosphere," Contributions of the Geophysical Institute of the Slovak Academy of Sciences, vol. 24, no. 151, pp. 163-187, 1954.

[13] Z. I. Janjic, “The surface layer in the NCEP Eta Model," in Proceedings of the 11th Conference on Numerical Weather Prediction, pp. 354-355, American Meteorological Society, Norfolk, Va, USA, August 1996.

[14] J. Dudhia, "A multi layer soil temperature model for MM5," in Proceedings of the 6th PSU/NCAR Mesoscale Model Users' Workshop, pp. 49-50, Boulder, Colo, USA, July 1996.

[15] F. Chen and J. Dudhia, "Coupling and advanced land surfacehydrology model with the Penn State-NCAR MM5 modeling system. Part I: model implementation and sensitivity," Monthly Weather Review, vol. 129, no. 4, pp. 569-585, 2001.

[16] E. J. Mlawer, S. J. Taubman, P. D. Brown, M. J. Iacono, and S. A. Clough, "Radiative transfer for inhomogeneous atmospheres: RRTM, a validated correlated-k model for the longwave," Journal of Geophysical Research D, vol. 102, no. 14, pp. 1666316682, 1997.

[17] J. Dudhia, "Numerical study of convection observed during the Winter Monsoon Experiment using a mesoscale twodimensional model," Journal of the Atmospheric Sciences, vol. 46, no. 20, pp. 3077-3107, 1989.

[18] J. S. Kain and J. M. Fritsch, "A one-dimensional entraining/detraining plume model and its application in convective parameterization," Journal of the Atmospheric Sciences, vol. 47, no. 23, pp. 2784-2802, 1990. 
[19] J. S. Kain, "The Kain Fritsch convective parameterization: an update," Journal of Applied Meteorology, vol. 43, no. 1, pp. 170181, 2004.

[20] B. S. Ferrier, Y. Lin, T. Black, E. Rogers, and G. DiMego, "Implementation of a new grid scale cloud and precipitation scheme in the NCEP Eta model," in Proceedings of the 15th Conference on Numerical Weather Prediction, pp. 280-283, American Meteorological Society, San Antonio, Tex, USA, 2002.

[21] G. C. Holtzworth, "Mixing depths, wind speeds and air pollution potential for selected locations in the United States," Journal of Applied Meteorology, vol. 6, no. 6, pp. 1039-1044, 1967.

[22] J. Stensrud David, Parameterization Schemes Keys to Understanding Numerical Weather Prediction Models, Cambridge University Press, 2007. 

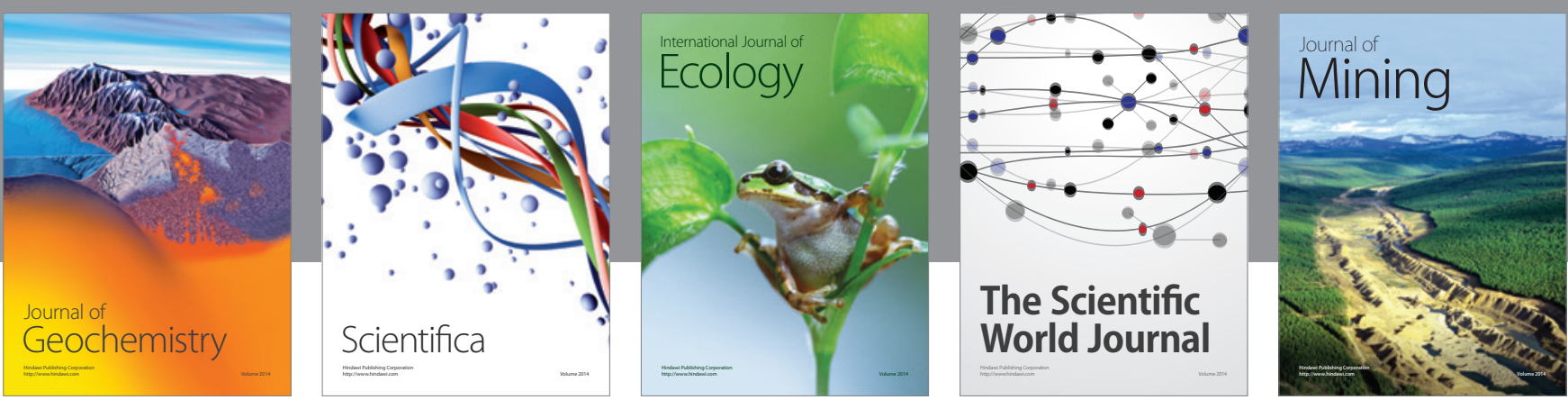

The Scientific World Journal
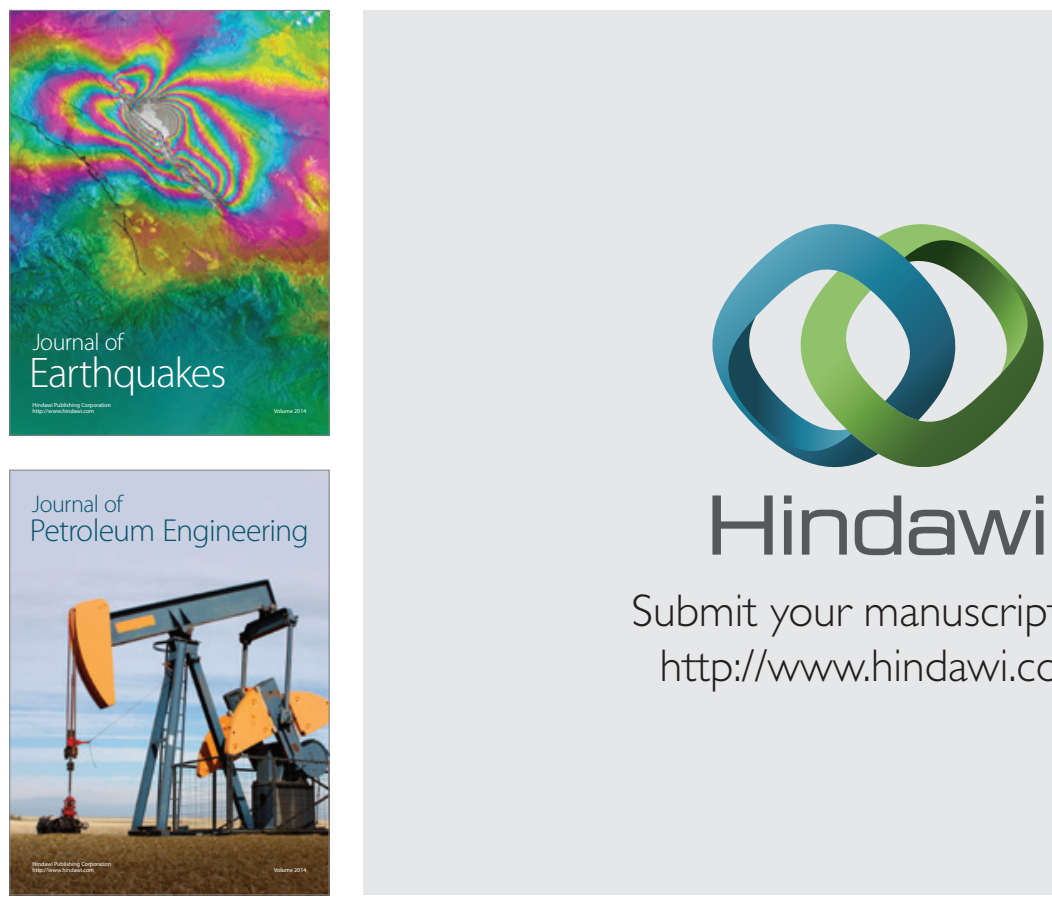

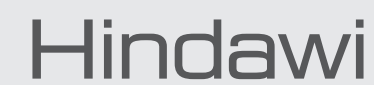

Submit your manuscripts at

http://www.hindawi.com
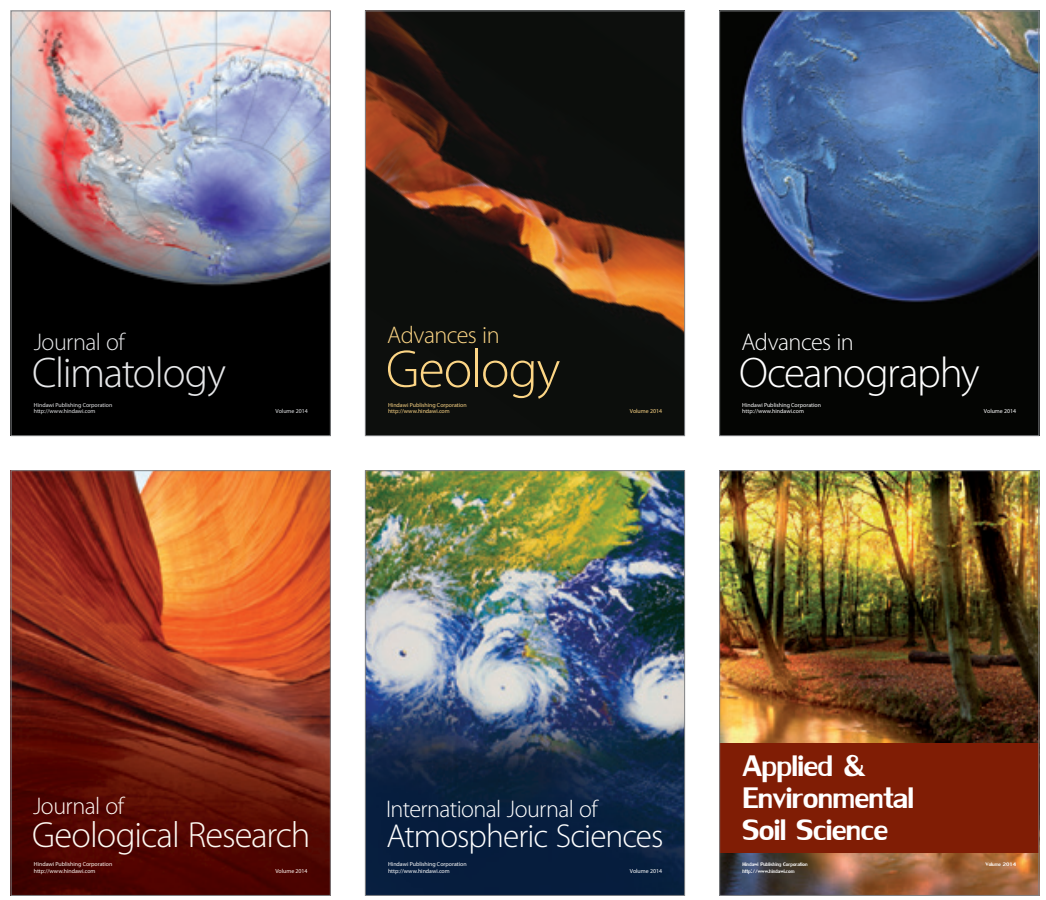
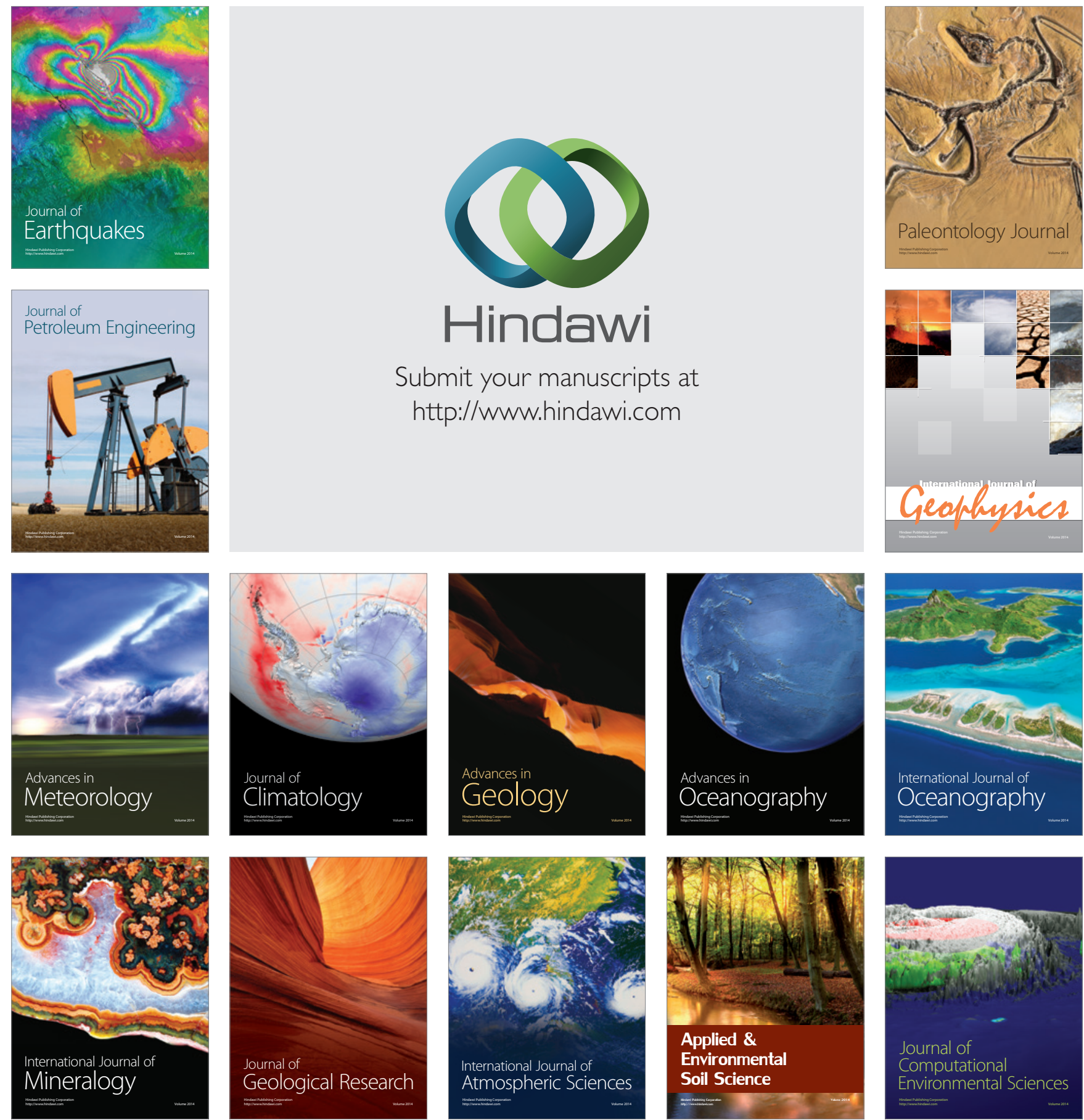